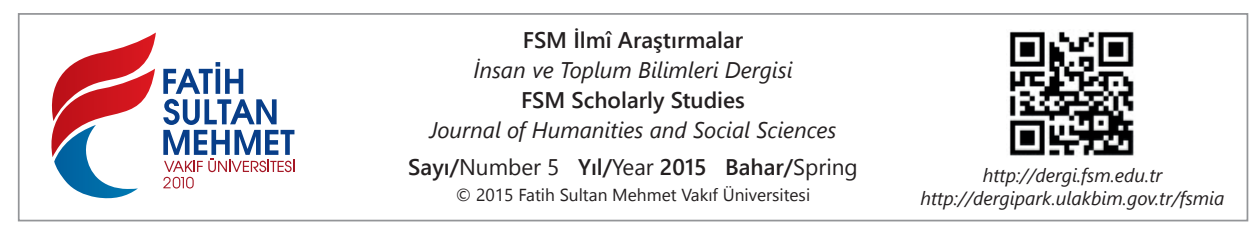

\title{
Concept of Barakah in Qur'ān and Sunnah: Towards its Realization in Modern Discourse
}

\author{
Serdar Demirel* \\ Hikmatullah Babu Sahib**
}

\begin{abstract}
One of the concepts Islam considers important for human prosperity is the concept of barakah (Divine blessing). It is the increase in quality and quantity of God's blessing via unseen ways to human life. The word barakah also means to make the felicity constant and permanent, which also means abundance and the continuity of that. However, with modernity barakah has become an alienated concept in the life of modern man. This research explores and discusses the reasons behind the lack of divine blessing in human life in modern times and the profane worldview behind it by highlighting its importance and application through both Qur'ānic and Sunnah texts.
\end{abstract}

Keywords: Barakah, Qur'ān, Sunnah, modernity, profane life, realization.

\section{Özet}

\section{Kur'an ve Sünnet'te Bereket Kavramı: Modern Diskurda İdrakına Doğru}

İslâm'ın insan hayatının refahı ve huzuru için önemsediği önemli kavramlardan birisi de bereket kavramıdır. Bereket ise, Allah'ın insanın yaptıklarını keyfiyet ve kemiyet olarak görmediği yollardan artırmasıdır. Aynı zamanda sadetin devamlı ve kalıcı olmasını da ifade eder. Ancak moderniteyle beraber insanın yabancılaştığ 1 bir kavramdır. Bu araştırma, profan modern hayatta bereketin azalmasının sebeplerini incelemekte ve İslâm'ın iki ana referans kaynağı olan Kur'an ve Sünnet'e göre bereketin anlamlarını, ehemmiyetini ele almakta, Hz. Peygamber'in hayatında bereket arayışını göstererek modern diskurda neye tekabül ettiğini incelemektedir.

Anahtar Kelimeler: Bereket, Kur'an, sünnet, modernite, profan hayat, idrak.

* Associate Professor, Fatih Sultan Mehmet Vakif University Faculty of Islamic Sciences, Istanbul/Türkiye, sdemirel@fsm.edu.tr

** Assistant Professor, International Islamic University Malaysia Kulliyah of Islamic Revealed Knowledge and Human Sciences, Malaysia, hikmatullah.sahib@gmail.com 


\section{Introduction}

One of the concepts Islam considers important for human prosperity is the concept of barakah (Divine blessing) - an alient concept to modernity. This may be the reason that this concept and its derivatives have been mentioned repeatedly in the Noble Qur'ān. It can be said that, barakah is the increase in quality and quantity of God's blessing via unseen ways to human. It is, in fact, an invisible blessing that manifests itself as an increase that cannot be calculated in material terms encompassing the whole human affairs. The word barakah also means to make the felicity constant and permanent, which also means abundance and the continuity of that. But, with modernity barakah has become an alienated concept in the life of modern man. Thus humanity suffers the results together. This is because modernity denotes a transition period in which the human mind is cleared off the sacred and being appraised in a reductionist fashion, mincing a worldview which encompasses both physical and metaphysical perspectives into a merely corporeal and physical one. Modernity secularized the human perception by means of the worldviews it generated. In this respect it legitimized fostering a relationship with things in a manner independent from the sacred. Once the perception became profane, then it is impossible for the values to orientate the human behaviour. Thus barakah is one of the concepts that need to be "cured". This research explores and discusses the reasons behind the lack of divine blessing in human life in modern times and the profane worldview behind it by highlighting its importance and application in the light of both, the Qur'an and Sunnah.

\section{A Break in the History: Modernity}

Modernity does not indicate a break in the relationship of man, religion and metaphysical world, as it is impossible to speak about a society in a geographical or cultural sphere that is not affected by this phenomena. Modernity refers to a transition period in which the human mind is freed from the sacred and reduced to a pure physical world perspective bereft of any metaphysical aspect of being.

Modernity secularized the perception of man by means of the worldviews it produced. It legitimized engaging in a relationship with things independent from the holy and sacred. And whence perception became profane values no longer could influence the human behaviour. Modernity was an antithesis to religious values to act as mediator and orientation point in the relationships between individuals; between members and the society; and between the society and the state. It essentially based the understanding and interpreting of the existence "here' (in the present world) to "now" (present time). Secularism, in this context, constitutes the hardest core of the modern life speculation.

This paper particularly wants to underline the fact that whenever it discusses about modernity, it alludes to the "secular paradigm" from which "many wor- 
ldviews" proliferate. It is not possible to tackle the issue by assigning it merely to the technical aspects modernity produces. As the gigantic technological achievements stand like a spectre between man and the paradigm created by this technology, the vast majority fail to see the profane worldview disguised by this modernity. It is due to the technological success that the eyes of man are dazzled and he fails to see the relation between modernity and many other contemporary dilemmas he falls into. It is a situation that gains legitimacy, when the subject is abated to technology. However, modernity expresses more than one secular worldview; it connotes rather a lifestyle constructed by these worldviews devoid of the sacred. The most problematic area of this speculation is absolutely the exclusion of the sacred.

Religious break, as an inevitable result of modernity, did not emerge overnight; and of course it could not have been. This break started from a centre point just like ripples on the water; and it expanded with activities of various moving forces to the whole area that the same water spanned over. This transition originated in Europe and penetrated the whole world within centuries. Therefore, we can speak of the modernization of Turkish and the Arab world; or modernization of Japan and China only separately since they emerged in different cultural spheres although they share the same core. Thus, one has to examine the emergence of modernity historically, even at a brief glance, as to read the modernity correctly. For, no social phenomenon emerges out of nowhere; absolutely there exists a chain of events or a logical base that lays the foundation for a phenomenon. In what follows a brief but succinct summary of the historical background of the emergence of this phenomenon is provided.

Renaissance in the sense of "rebirth" and "resurrection" started in the $16^{\text {th }}$ century Italy as a movement of retreat to the ancient art of Greek and Rome. Eventually, it evolved into a movement of thought and action in a way unbounded by religio-centricism. It gained the identity of being a poser against the Scholastic Medieval Worldview - a philosophical doctrine based on explaining faith and knowledge by means of the teachings of the Church and the conceptions of Aristotle. What ignited modernity in essence is this Renaissance movement which amalgamated ancient Greek culture with Medieval culture, thus giving birth to a new understanding of the existence based on human rationale.

At the beginning, renaissance did not denote an essential break from religion. It brought a different perspective to religious reading. It was an objection to church's understanding and interpretation of religion. The attempt to integrate new interpretations to the methodology of the church and its religious practices was an important aspect. Thus, it aimed to unbridle religious reading and interpretation of religion from the monopoly of the church and clear the path of individual interpretation of the scripture by man himself. Of course, in essence this reading 
laid the basis of an approach, which wanted to emancipate itself from the central religious criteria established since centuries and from the methodology built on these criteria with the aim to replace them with the individual "mind".

It was not a coincidence that renaissance originated from the world of Christianity. In the Christian world, religion was under the monopoly of the church, and the clergy, acting on behalf of God on earth, was dominating the political life. Eventually this movement assumed the mission of bringing an end to this situation. In this respect, reform can be read as the reflection of renaissance on the perception of religion, religious institutions and practices.

The $17^{\text {th }}$ century is known as the "Age of Reason". Philosophers like Francis Bacon, Pascal, Hobbes, Galileo, Descartes and Spinoza injected into the prevalent philosophical endeavours various anticipations such as: man is an intelligent being, lives in an intelligent planet designed by an Intelligent and Wise God, there is a relation between intelligence and nature, it is possible to grasp the mysteries and the secrets of the planet if the intelligence becomes the essential centre in life and the resulting knowledge can be used for the sake of humanity. This idea eventually became the lever of the Enlightenment which emerged during the following century. ${ }^{1}$

The $18^{\text {th }}$ century is the "Age of Enlightenment" in the history of Western politics and thinking. ${ }^{2}$ Many thinkers of the era such as Locke, Berkeley, Volta-

1 http://en.wikipedia.org/wiki/The Age of Reason /, accessed on: 11-05-2015.

2 Commenting on this, Gillespie, in the preface of his recent work pleads in defends of modernity saying that, "Indeed, since the time of the Enlightenment modernity has thought of itself as an effort to suppress religious superstition and authority, encapsulated in Voltaire's famous imperative: 'Ecrasez l'infame!' In Europe this has meant a continual diminution of the importance of religion, confining it first 'within the bounds of reason alone,' as Kant put it, then attempting to put it out of its misery by declaring God was dead, and culminating in the exceptional decline in religious belief and practice in the latter half of the twentieth century. Even in America, where religion continues to play a much more important role than in Europe, the attachment to religion is often perceived, especially by intellectuals and academics, as atavistic and unseemly, especially when it takes on a fundamentalist or evangelical tone. And even in America, the idea that religion should guide public life continues to meet widespread opposition. This opposition to religion in the modern age, however, should not be taken as a proof that at its core modernity is antireligious. It is certainly true that modernity has consistently struggled against certain forms of religious doctrine and practice, including the cult of the saints, teleology, the natural law teachings of scholasticism, the geocentric vision of the natural world, and creationism, but I want to suggest that this does not mean that it was therefore a rejection of religion as such. The argument presented in this book suggests that it is a mistake to imagine that modernity is in its origins and at its core atheistic, antireligious, or even agnostic. Indeed, I will show in what follows that from the very beginning modernity sought not to eliminate religion but to support and develop a new view of religion and its place in human life, and that it did so not out of hostility to religion but in order to sustain certain religious beliefs. As we shall see, modernity is better understood as an attempt to find a new 
ire, and Hume advanced the philosophical approach of the Age of Reason ${ }^{3}$ and claimed that man lives in an intelligent planet and in order to grasp the rules of the planet, he does not need super or omnipotent entities. They emphasized that man must be emancipated from the shackles of religion in terms of understanding and interpretation. Nature should be contemplated without referring to metaphysical entities. ${ }^{4}$

Thus, "Enlightenment" aimed at freeing man from religion, theological and scholastic understandings of the church, traditional views and social criteria by means of touting his intellect as the essential means for his intellectual ventures. It was crucial to build a life based on intellect in all its aspects ranging from politics to economy, from education to any vital fields of life. This thought which significantly flourished in a Western European country, England, expanded to France, Holland, Germany and other European countries and constituted the basic paradigm of the modern era.

Enlightenment is the name of a new paradigm shift, a break from the Christian scholastic thought which dominated the European Continent. It studied the universe, the planet which man inhabits and many other values that are important to man himself, in a perspective solely founded on empirical evidence, experiment and intellect with no reference to metaphysical aspects. This approach claimed that an eternal development could be achieved and, thus, man would be happier with his material developments and achievements. This era, in other words, shows a paradigm shift, which evolved into secular worldview from a religio-centric worldview. This shift culminated in the "Age of Ideologies."

The $19^{\text {th }}$ century, therefore, was named as the "Age of Ideologies"5; or "Existentialism". The important figures of the era were Kant, John Stewart Mill, Nietzsche, Marx, Hegel, and Kierkegaard. In this era, contradicting ideologies produced many social engineering projects under the same claim of building a

metaphysical/theological answer to the question of the nature and relation of God, man, and the natural world that arose in the late medieval world as a result of a titanic struggle between contradictory elements within Christianity itself."

For detailed discussion see, Gillespie, Michael Allen, The Theological Origins of Modernity (Chicago / London: The University of Chicago Press, 2008), pp. xi-xii.

3 For discussion on the Age of Reason readers are referred to Paine's thought-provoking book made available by Steve Thomas. See Paine, Thomas. The Age of Reason (South Australia: The University of Adelaide, 2010). Available at http://creativecommons.org/licenses/by-nc-sa/2.5/ $\mathrm{au} /$, accessed on $26^{\text {th }}$ March 2011.

4 Lawhead, William F, The philosophical journey: an interactive approach, (New York, NY: McGraw-Hill, 2009, $5^{\text {th }}$ ed) http://en.wikipedia.org/wiki/Age of Enlightenment, accessed on: 11-05-2015.

5 Schwarzmantel, John, The Age of Ideology: Political Ideologies from the American Revolution to Postmodern Times, (New York: NYU Press, 1998). 
heaven on earth. Their common goal was to make man happy, to establish a fair and peaceful order in the world, to advance humanity to abundance and welfare. However, many ideologies emerging under these notions created totalitarian regimes. As they conceive religion as a threat, or an opium that narcotizes people, they either destroyed or tried to control everything pertaining to religion. Of course there were other ideologies with moderate approaches. However, like their extremist counterparts, their common ground was their faith in secularism. Materialism nurtured by secularism destroyed people's sense of religiosity and barakah in their life.

The period between 1630 and 1940 is defined as modernity by referencing the events of this period. The period after 1940 is, thus, defined as post-modernity by the same token. However, post-modernity only acts as a philosophical thought within a limited field of activity. In fact, vast majority of the world still experiences the period of modernity.

Modernity is the shared womb for the Western ideologies that emerged within the period mentioned above. Contrary to all its humanitarian statements, its consequence for the world was a total destruction; it cost two World Wars, weapons of mass destruction, huge environmental problems and masses of individuals disintegrated to their atoms in an ideological sense. The emergence of post-modernity was a reaction to this modern failure.

Modernity, the detaching of meaning from transcendental, tried to satisfy questions on existence by forging answers from physical world. Most of the time, it labelled these answers as "scientific facts". In terms of modernity, religion is a phenomenon created by man and thus the answers of religion cannot be scientific. Man, when he spoiled the relationship between Allah and himself by paralyzing his relationship with religion, he is alienated from Allah, and in return Allah forgets him. ${ }^{6}$

We do not claim that in the pre-modern world everything was proper and the world was a heaven. Instead we are talking about the history of man, who is prone to committing mistakes, not the history of infallible angels. We also admit that modernity had positive contributions to the man's scientific pursuit. However, our main assertion is that the main problem of the modern era is to detach existence and man from spirituality by striving to make his physicality as his only reality. Modernity aims to detach the codes of human mind from the sacred and the "modern man" is a culmination of this process. The underlying and true meaning of this process unfolds itself in the relationship between man and his surroundings. 
Today, we live in a world where people educated in systems adopting strict materialistic worldviews have a distorted vision of the concept of "barakah". We know that doubtful growls arise against this concept from the reminiscent of secular philosophy at the ridges of their brains. However, the word barakah was repeated 32 times in the Qur'än because of its importance and, thus, people's attention should be attracted to this crucial concept.

\section{Defining Barakah}

The term barakah originating from the trilateral verb $\boldsymbol{b}$ - $\boldsymbol{r}$ - $\boldsymbol{k}$ means growth, appreciation, happiness and excess. ${ }^{7}$ As a verbal noun it also denotes "blessing and benediction" a quality that entails the power to work miracles of a predominantly beneficial character. Its related verb forms II, III, V, VI and X are all related to the notion blessing. However, Mitchel has questioned their etymological relation to the original root word $b-r-k$ "to kneel down (the camel)" or with its noun form birkah meaning "pond, small lake or pool". ${ }^{8}$ Responding to this query, Chelhod claims that there is clear relation between the root $\boldsymbol{b}-\boldsymbol{r}-\boldsymbol{k}$ and the noun barakah, since "the blessing power originally was either the bodily power to stand up or was the power of good fortune which resulted in numerous camels since baraka could denote group of kneeling camels and prosperity in general"'. This concurs well with the ancient Arabian idea of having the camels kneeling down to take rest at the yard of wealthy Arabs signifies the status of the owner which was regarded as a divine favor. As for the second meaning of the word relating to pond and lakes, there seems to be no etymological correlation between the root and the verbal noun, except that it could be conjured to mean that the possessor of a spring in the arid and water-scant region of the desert is considered to be blessed compared to those who do not own such resource.

However, here one may be tempted to know what the kneeling of the camel has to do with human in respect of the root $b-r-k$. The only plausible explanation could be found on the fact that man kneels down in veneration during his service to God to reflect his reverence to his superior. Still this only establishes the variation in respect of the meaning in its linguistic sense without there being any obvious common features shared by them. But one thing remains constant in the sense that this blessing establishes a favourable disposition between the blesser

7 See Ibn Manẓūr, Muḥammad Bin Makram. LisÉn al- 'Arab, (Bairut: Dār Șādir, $1^{\text {nd }}$ edition.), 10/395, Al-Fayrūz Ābādī, Muhammad Bin Yaqūb. Al-Qamūs al-Muhīṭ, (Bairut: Muassasat alRisālah), p. 1204.

8 Mitchell, Christopher Wright, The Meaning of BRK "To Bless" in the Old Testament, (Atlanta: Scholars Press, 1987), p. 11.

9 Chelhod, Joseph, "La baraka chez les Arabes ou l'influence bienfisante du sacré", Revue de l'histoire des religions, 148 (1955), p. 78. 
and the blessed. This blessing could be in the form of speech or action. If it is in the former, it may be termed as benediction and in the later sense it is known as benefaction. Both these aspects express the good nature of the blesser. Since God is the blesser He needs to be blessed Himself. It is in this meaning He is attributed with barakah by the usage of a derivative of $b-r-k$, tabarak, meaning "the Self-Blessed" and as mubārak "the Blessed". Commenting on this reference on God and it being specified on selected members of His creation out of His grace, Ibn al-Qaiyyim says ${ }^{10}$ :

If the barakah in its totality belongs to God, the Self-Elevated, and emanated from Him, then it is because He is Mubarak (the blessed), and whosoever on whom His barakah is attributed then he is blessed. It is due to this His Book is Blessed, His Messenger is Blessed, His House is Blessed, the time which $\mathrm{He}$ ennobled and specified from those other than it is Blessed, the Night of Power is Blessed, the vicinity of Masjid al-Aqsa is Blessed, the land of Syria is described as Blessed in four or five places in His Book, He is Self-Blessed in His Essence, Who Blesses whosoever He wishes amongst His creation...

Muslims understand this blessing as a "beneficent force, of divine origin, which causes superabundance in the physical sphere and prosperity and happiness in the psychic order" ${ }^{\prime 1}$. As such for Muslims it is a gift or bounty from God to one whom He chooses out of His love in appreciation of servant's obedience and submission to His will. This gift or bounty could be in many forms. It may be in the form of knowledge, wisdom, qualities, skills, wealth, health, or family. To Ibn 'Abbās, barakah means abundance in every auspicious and good deed. ${ }^{12}$ The Noble Qur'ân makes repeated references to the term in the form of its derivatives in the following verses:

10 Ibn Qaiyyim al-Jawziyah, Abi 'Abd Allāh Muḥammad ibn Abi Bakr al-Dimashqi, Badā ' $i$ ' alFawā'id, (Misr: Maktabat al-Qāhirah, $2^{\text {nd }}$ edition, 1972), pp. 186-7.

11 See "Baraka" in The Encyclopedia of Islam, (New Edition, 1960).

12 See Ibn Manzūr, Lisān al- 'Arab: 10/395. 


\begin{tabular}{|c|c|c|c|}
\hline Derivatives of barakah & \multicolumn{2}{|c|}{ Qur'ānic Reference } & Area of Concern \\
\hline bāraka & Fussilat & $(41: 10)$ & Things (provisions) \\
\hline \multirow{6}{*}{ bāraknā } & Al-A'rāf & $(7: 137)$ & Place (East and West) \\
\hline & Al-Isrā' & $(17: 1)$ & Place (Masjid Haram \& Aqsā) \\
\hline & \multirow{2}{*}{ Al-Anbiyā' } & \multirow{2}{*}{$\begin{array}{l}(21: 71) \\
(21: 81)\end{array}$} & Place (Lut and Ibrāhim) \\
\hline & & & Place (Sulaymān) \\
\hline & Saba' & $(34: 18)$ & Place (Yemen and Shām) \\
\hline & Al-Sāffāt & $(37: 113)$ & Person (Ibrahim and Ishaq) \\
\hline būrika & Al-Naml & $(27: 8)$ & $\begin{array}{l}\text { Occasion (Musa and burning } \\
\text { Bush) }\end{array}$ \\
\hline \multirow{7}{*}{ tabāraka } & Al-A'rāf & $(7: 54)$ & \multirow{7}{*}{$\begin{array}{l}\text { God (Creator of the Universe) } \\
\text { God (Creator of Man) } \\
\text { God (Creator of Qur'ān) } \\
\text { God (Creator of the Heaven) } \\
\text { God (Creator of Constella- } \\
\text { tions) } \\
\text { God (Lord of the Universe) } \\
\text { God (Owner of all things) } \\
\text { God (Name) } \\
\text { God (Possessor of Power) }\end{array}$} \\
\hline & Al-Mu'minun & $(23: 14)$ & \\
\hline & Al-Furqān & $\begin{array}{l}(25: 1) \\
(25: 10) \\
(25: 61) \\
\end{array}$ & \\
\hline & Ghāfir & $(40: 64)$ & \\
\hline & Zukhruf & $(43: 85)$ & \\
\hline & Al-Rahmān & $(55: 78)$ & \\
\hline & Al-Mulk & $(67: 1)$ & \\
\hline \multirow{2}{*}{ barakāt } & Al-A'rāf & $(7: 96)$ & Unspecific things \\
\hline & Hud & $(11: 48)$ & Favor \\
\hline barakātuh & Hud & $(11: 73)$ & Family / descendant \\
\hline \multirow{3}{*}{ mubārak } & Al-An‘ām & $\begin{array}{l}(6: 92) \\
(6: 155)\end{array}$ & Thing (Qur’ān - ) \\
\hline & Al-Anbiyā' & $(21: 50)$ & Thing (Qur'ān - Dhikr) \\
\hline & Sād & $(38: 29)$ & Thing (Qur'ān - Reflection) \\
\hline \multirow{4}{*}{ mubārakan } & Al-i-Imrān & $(3: 96)$ & Place (Bakkah / Ka‘bah) \\
\hline & Maryam & $(19: 31)$ & Person (Jesus) \\
\hline & Al-Mu'minun & $(23: 29)$ & Place (location of landing) \\
\hline & Qāf & $(50: 9)$ & Thing (rain) \\
\hline \multirow{4}{*}{ mubārakatan } & \multirow{2}{*}{ Al-Nur } & \multirow{2}{*}{$\begin{array}{l}(24: 35) \\
(24: 61) \\
\end{array}$} & Thing (tree) \\
\hline & & & Act (greeting) \\
\hline & Al-Qasas & $(28: 30)$ & Place (Oasis) \\
\hline & \multicolumn{2}{|l|}{ Al-Dukhān } & Time (Laylat al-Qadr) \\
\hline
\end{tabular}


Thus the term barakah has been used to denote the blessings bestowed upon the people, their places and time or occasions, and even on things materials like water, olive, dates, cheese, cattle, horse, etc. Qur'ān also links barakah of the places to the prophets who lived there and spread the religion among those who inhabited them. It also states the fate of those revolted against the message, thus:

"If only had the people of those countries believed and avoided to oppose and revolt against Him they would receive barakah both from the skies and from the earth; but they rejected and denied and thus they captured/punished. (alA'rāf 7:96).

It can be proposed that barakah is the proliferation in quality and quantity of the things material or otherwise by God via unseen ways to man encompassing his multi-dimensional avocations. This can at times manifests itself through select people and things. For instance, to kiss the black stone (hajar al-aswad) of Ka'bah is considered as barakah. Addressing this stone, the second Khalifah, 'Umar Ibn al-Khattab is reported to have said: "I know you are a stone that neither harms nor helps, and had I not seen God's messenger kiss you, I would not have kissed you". Thus, this divine blessing covers the entire aspects of a man's life be they in this world or in the hereafter. This is illustrated in the figure below:

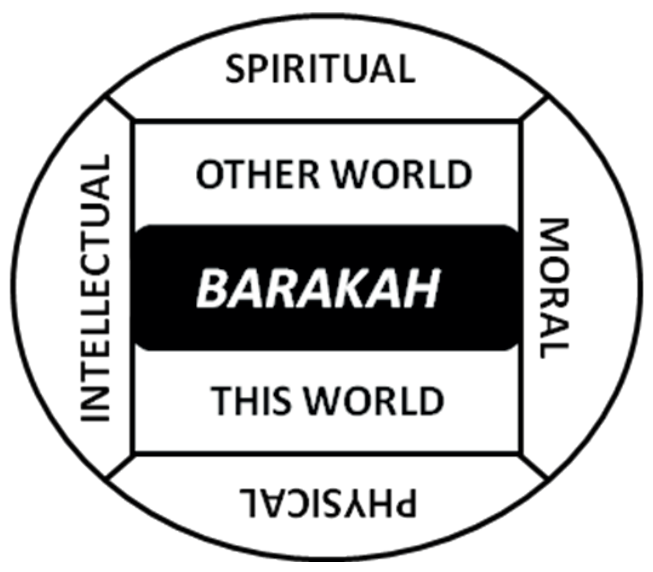

\section{Barakah in Teaching of the Prophet (p.b.u.h)}

Words and deeds, nay the entire life of the Prophet was imbued filled with barakah. He has outlined for us through his blessed life the occasions that attracts and dispels divine blessings. The hadith collections have captured faithfully the various statements and actions of the Prophet wherein he has reiterated the importance of this concept, which is valid both for quality and quantity of our con- 
ducts and affairs pertaining to our total (meaning material and spiritual) lives. The Prophet was so concerned about the very usage of the word barakah that in a hadith narrated by Jabir bin 'Abd Allah wherein Prophet disapproved the naming of anyone as Ya'la (Elevated), Barakah (Prosperous), Aflah (Successful), Yasar (wealthy) and Nafi' (Beneficial). ${ }^{13}$ Explaining this hadith, Abū Dāwūd gives the reason for the Prophet's disdain for such usage as follows: "...If someone is named as Barakah and when somebody looks for that person and asks "Is Barakah here?" and they may answer saying "No, Barakah is not here!". ${ }^{14}$ Thus this illustrates the concern the Prophet had for the term such that he does not approve the arbitrary usage of it even to name a person with it. In the following pages an attempt is made to present this concept as envisaged by the Prophet. Among the teaching of the Prophet that attracts barakah are:

\section{[a] Truthfulness in dealing}

The Prophet (p.b.u.h) is reported to have said: "Both parties in a business transaction have the right to accept or reject the deal as long as they have not parted or till they part. If they tell the truth and make everything clear to each other (e.g. described the defects and qualities of the goods), then their transaction is blessed. If they conceal anything and lie to each other, the blessing of their transaction will be eliminated." 15

The above ahadith are sufficient in stressing the importance of those involved in business transactions to be honest and truthful. It is interesting to note that, the Prophet guaranteed barakah for those who were truthful and honest in carrying out business deals. We understand through this report that the concept of barakah provides a guarantee of eventual success and reward for truthfulness and honesty, regardless of what the immediate and apparent results might be. The Prophet also said: "Beware of swearing, it produces a ready sale for a commodity, but obscures the barakah." 16 The Messenger did not deny that swearing may encourage sales, but he warned that it removes the barakah of the transaction. ${ }^{17}$

13 Al-Qushayrī, Muslim Bin Ḥajjāj. Șaḥ̄h Muslim, Ed. Muhammad Fu'ad 'Abd al-Bāqīe (Bairut: Dār Ihyā al-Turath al- 'Arabī), 3/1686 hn. 2138; Abū Dāwūd, Sulayman Bin Al-Ash'as. Sunan $A b \bar{\imath}$ Dāvūd, Ed. Muhammad Muhyiddin Abd Al-Hamīd, (Dār al-Fikr), 4/290 hn. 4960. Wording of hadith belongs to Muslim.

14 Abū Dāwūd: 4/290 hn. 4960.

15 Bukhārī, Muḥammad Bin Ismāil. Șaḥ̄ḥ al-Bukhārī, Ed. Mustafā Dīb al-Bughā, (Bairut: Dār Ibn Kashir al-Yamāma, $3^{\text {st }}$ edition), 2/743 hn. 2004; Muslim: 3/1164, hn.1532; Abu Dāwūd: $3 / 273$ hn. 3459.

16 Bukhārī: 2/735, hn. 1981; Abu Dāvūd: 3/245, hn. 3335.

17 See Al-'Azīm Ābādī, Muhammad Shamsul Haq. Avn al-Ma'būd Sharh Sunan Ab̄̄ Dāwūd. (Bairut: Dār al-Kutub al- ‘̄ilmiy, $2^{\text {nd }}$ edition, 1995), 9/132. 


\section{[b] Increasing forgiveness and greetings}

The Prophet is reported to have said, "if anyone keeps on seeking forgiveness God will make for him a way out of every distress and a relief from every anxiety and will provide for him from where he did not reckon"18.

Muslims greet each other as they gather, they meet each other, or they leave a place by saying "Assalāmu Alaikum Warahamatullahi Wabarakatuh". This greeting is a wish for peace, tranquility and happiness. The one who greets wish peace and happiness for the other from Allah whose one of the beautiful names is al-Salām which means "peace". Anas, one of the Prophet's companions, narrated that the Messenger of Allah (p.b.u.h.) commanded him as: "My dear son, every time as you entered in to your house salute everyone; thus may your salām (i.e.: salutation) becomes barakah upon you and your family!"19

\section{[c] Increasing the praise of Allah at all time and occasion}

\section{Barakah prayer on the resident}

Anas narrated that the Prophet prayed as: "O, My Almighty Allah! Bless Madinah with barakah twice that of Your blessing for Makkah!" ${ }^{20}$ It is considerably difficult for the modern intellect to understand asking barakah from Allah upon a city and its residents. However the Messenger of Allah wishes both material and spiritual barakah for the places humans live.

\section{Saluting the early fruits of the year with blessing prayers}

Abu Hurayra reported that the Messenger of Allah was given the first fruit of the season and he said: My Almighty Allah, show your blessings upon us in our city, and in our fruits, in our mudd (two standards of weight and measurement) and in our sa's, blessings upon barakah, and he would then give that to the youngest of the children present there." ${ }^{21}$

\section{Praying for the barakah of the things done in the early morning}

"The Messenger prayed as: "My Almighty Allah; bless the deeds of my community that they accomplish on the early mornings." 22

18 Ibn Ḥanbal, Abū 'Abdullah Aḥmad al-Shaybānī. Musnad Ahmad, (Egypt: Muassasat Qurtubah): 1/248; Al-Bayhaq̄ī, Ahmad Bin Hossain. Sunani Al-Bayhaqī Al-Kubrā, Ed. Muḍammad Abd Al-Qādir Atā, (Makkah: Dār Al-Bāz, 1994), 3/351.

19 Tirmizī, Muḥammad Bin 'Isā. Sunan al-Tirmizī, Ed. Aḥmad Muḥammad Shākir, (Bairut: Dār Ihyā al-Turath al-Arabī): 5/59, hn. 2698.

20 Bukhārī: 2/666, hn. 1782; Muslim: 2/994, hn. 1369,; Musnad Aḥmad: 3/142, hn. 12475.

21 Muslim: 2/1000, hn.1373; Al-Qazwīnī, Muhammad Bin Yazīd. Sunan Ibn Mājah, Ed. Muḥammad Fu'ad 'Abd al-Bāqī, (Bairut: Dār al-Fikr), 2/1105, hn. 3329.

22 Ibn Ḥibbān, Muḥammad Bin Aḥmad Abū Ḥātim. Sahīh Ibn Hibbān. Ed. Shuayb al-Arnawūt, (Bairut: Muassasat al-Risālah, $2^{\text {nd }}$ edition, 1993), 11/62, hn. 4754; Abū Dāwūd: 3/35, hn. 2606; Sunani Al-Bayhaqī Al-Kubrā: 5/258, hn. 8833. 


\section{[d] Marriage}

It is recorded Abu Hurayra states as: "The Messenger of Allah congratulates the newly married couple as: "May Allah bless your wedding, may He brought barakah upon it, may your lives come together in a good deed". ${ }^{23}$

\section{[e] Eating manners}

Abu Hurayrah states as: "One day I came by Mohammed the Prophet with some dates (fruit) on my hand and said: "O Messenger of Allah, please, pray upon these for abundance!." And as of that moment he collected them and prayed for barakah. And then he said: "Put those into your store bag. Whenever you want something, put your hand in it and take it. Never open and dispose the things in it!" And I did so. And I gave some vask ${ }^{24}$ of it as a charity in on the way of Allah. We ate from it and gave people to eat from it. I never detached it from my waist. This continued until the day 'Uthmān ibn 'Affān was murdered. On that day it detached." ${ }^{25}$ Ahādith as such show that how foods such as dates and others can be blessed and increased through prayer in quantity as the Prophet did.

Anas reported that the Messenger of Allah commanded: "Eat your meal at sahur; hence there is barakah at sahur." 26 The barakah during sahur is the blessing emerged as a result of the intentions of prayer and awe special to this time of the year. As Allah is pleased with the man's ('abd) intentions and affairs, $\mathrm{He}$ proliferates what he possesses.

Salman, the well-known companion of Persia said: "I've read in the Old Testament: It says "The barakah of the meal is washing hands and mouth after the meal." I told this to the Messenger. He replied: "The barakah of the meal lies in the washing of hands and mouth before and after the meal." ${ }^{27}$ Commentators of this hadith stated on this issue that, washing hands before meal shows the respect to the foods of Allah; and also allows sterilizing the hands and washing after meal clears the remains of the meal. ${ }^{28}$ It is obvious that what has been underlined is essential for the human health and a good appearance.

23 Abu Dāvūd: 2/241, hn. 2130; Tirmizī: 3/400, hn. 1091; Musnad Aḥmad: 2/381, hn. 8943.

24 Vask: It is a unit of weight about $60 \boldsymbol{s} \boldsymbol{a}^{\prime}$. Where $\boldsymbol{s} \boldsymbol{a}^{\prime}$ ' is about 2.917 kilograms. (See Al-Mubārakfūrī, Muḥammad Bin 'Abdu Rahman bin 'Abdu Rahim. Tuhfatu al-Aḥwazì Bi Sharḥ̄ al-Jāmī al-Tirmizī, (Bairut: Dār al-Kutub al-'Ilmiy), 10/228)

25 Tirmizī 5/685, hn. 3839; Musnad Aḥmad: 2/352, hn. 8613; Șah̄̄h Ibn Hịbbān: 14/467, hn. 6532.

26 Bukhārī, 2/678, hn. 1822; Muslim: 2/770, hn. 1095; Tirmizī: 3/66, hn. 708.

27 Abu Dāvūd: 3/345, hn. 3761; Tirmizī: 4/281, 1846; Musnad Ahmad: 5/441, hn. 23783.

28 See Tuhfatu al-Ahwwazì: 5/470, Avn al-Ma'būd Sharh Sunan Abī Dāvīd: 10/168. 


\section{[f] Doing justice in weighing}

The Prophet is reported to have said "weigh your foods (so that) you will be blessed through it". ${ }^{29}$ This is a clear directive for us to be concerned with the utility of the food one consume such that there should be no wastage nor deception in the consumption of food be it for oneself or family. Thus care must be made in ensuring that even the proper intake of food for one's health can be considered as blessing, since one is doing justice by weighing the right calories, quality and quality of food one consumes. Certainly adhering to such noble directives will not only save ones money but also as a blessing in terms of health.

\section{[g] Generous in seeking and spending wealth}

According to the perception of the modern mind charity diminishes the commodity; however, it may seem so (virtually), according to Islam; charity granted in the name of Allah blesses the commodity and brings barakah. Allah, the Absolute Possessor, grants ways of increasing wealth for the person who willingly grants charity for the sake of Allah and warms the hearts of people to the charity giver; thus charity increases his trade potential. This teaching contradicts the modern mind which thinks and lives according to the parameters of materialism that are far from metaphysical understanding.

The Messenger said that "Wealth is not diminished by charity. Allah does not add anything to the servant for his pardoning except for honour, and none is humble for the sake of Allah except that Allah raises him." "30 The statement "Wealth is not diminished by charity" stated in the hadith above can either mean that charity brings about barakah and repels harm or that if even in reality wealth diminishes by giving charity, the reward gained not only compensates for the diminished amount but also proliferates it. ${ }^{31}$

In a narration, the Prophet was quoted as saying: "Save your commodities by alms, treat your patients with charity, prepare against the evil deed with prayers." ${ }^{32}$ Such a meaningful design that the word "alms" and "barakah" repeated so many times in Noble Qur'ān. Stinginess does not increase barakah and abundance; it rather will bring the wrath of Allah on the Judgement Day:

29 Bukhārī: 3/88, hn. 2128.

30 Muslim: 4/2001, hn: 2588; Tirmizī: 4/376, hn. 2029; Musnad Aḥmad: 2/235, hn. 7205.

31 See Al-Nawawī, Yahyā Bin Sharaf bin Mary. Sharh al-Nawaw̄ 'Alā Sahīh Muslim, (Bairut: Dār Ihyā al-Turath al-'Arabī, $2^{\text {nd }}$ edition, 1392 h.), 16/141.

32 Bayhaq̄ị, Sunani Al-Bayhaqī Al-Kubrā, 3/382, hn. 6385; Al-Tabarān̄̄, Sulaymān Bin Aḥmad. Al-Mu'jam Al-Kabīr, Ed. Ḥamdī Bin Abd Al-Majīd al-Salafì, (Musul: Maktabatu al-Ulūm wa al-Hikam, $2^{\text {nd }}$ edition, 1983), 10/128. 
"And let not those who covetously withhold of the gifts which Allah Hath given them of His Grace, think that it is good for them: Nay, it will be the worse for them: soon shall the things which they covetously with held be tied to their necks Like a twisted collar, on the Day of Judgment. To Allah belongs the heritage of the heavens and the earth; and Allah is well-acquainted with all that ye do." (Al-Imrān: 3/180)

\section{[h] Steadfast in prayers}

The Prophet of Allah embroidered his life with prayers for barakah and in every occasion He asked for barakah from Allah. And he taught this to the believers as he taught them the Noble Qur'an. Ibn 'Abbas reported: The Messenger of Allah used to teach us tashahhud just as he used to teach us a chapter of the Qur' an, and he would say: "All services rendered by words, (Mubarakat-Blessed) acts of worship and all good things are due to Allah. Peace be upon you, O Prophet and Allah's mercy and blessings. Peace be upon us and upon Allah's upright servants. I testify that there is no god but Allah, and I testify that Muhammad is the Messenger of Allah. In the narration of Ibn Rumb (the words are): "As he would teach us the Qur'an." ${ }^{33}$

\section{[i] Deeds that have permanent barakah even after death}

Deeds which contribute to the humanity and have beneficial effects on the life of other people are such deeds that bring about benefits for the person who carry out those deeds, even if they have passed away based on Islamic perspective. The Prophet said in this regard that; "When a person dies he is completely cut off except from three things: A running charity; knowledge that he had taught and remains putting to good use; and virtuous progeny praying Allah for him." 34

Secular understanding proposes a deed perspective which is founded only on "here" and "now"; therefore, it cannot grasp the idea of barakah in Islam. Although modernity continues to propagate the idea of enriching humanity by regarding selfishness as a virtue, the notions of value and barakah in Islam blesses and grants a prosperous life for the man via the positive and good deeds even after the connection between this world ends after death in a manner above the concept of time. To sum up; it can be said that the teachings of the Prophet advise continuously increasing deeds.

33 Muslim: 1/302, hn. 403; Ibn Ḥibbān: 5/282, hn. 1952; Abu Dāvūd: 1/256, hn. 974, Tirmizīi: 2/83, hn. 290.

34 Muslim: 3/1255, hn. 1631: Abu Dāwūd: 3/117, hn. 2880; Tirmizī: 3/660, hn. 1376. 


\section{The Biggest Factor That Declines Barakah in the Human Life: Sins}

The above mentioned ahadith illustrates how the Prophet organized the life around the quest for barakah based on intention and true faith. As the modern life impinges on a worldview confined to a material perspective, the barakah phenomenon is an alienated concept for us. The reason can be summed as follows:

Modern humanitarian statements that position humanity as the centre of the existence have infected the perception of Muslim masses. Therefore, the weaknesses and desires of man who has a tendency for sin are stimulated. Modernity, which positions man in the heart of the existence, deliberately targeted the religious provisions that confined man within its borders. Eventually, the vast majority of people embraced a free and materialistic way of life. It is a requirement of a priori; believing in Allah requires believing in a transcendental being that limits the life of man. The secular intellect cannot grasp this phenomenon. Alas! It was this desire of freeing human from all boundaries and limits that geared the processes behind modernity.

The human consciousness, which ideologically has a distant approach to modernity but couldn't defend itself against its charm contacts things with modern reflexes that constituted the relationship between commodity, material and itself. The modern education process that the human consciousness passed through rendered it to perceive the world in such a way. Therefore, human consciousness has become wounded, which in turn easily transgresses the borders of Allah by means of disregarding or interpreting them in line with modernity.

As the virus-infected modern mind persuades man to underestimate sins, sins themselves become smaller and insignificant, whereas the relevant punishment for these sins according to the Islamic Law seems bigger and bigger in our eyes resulting in the lack of a proper intervention that is inevitably stored in the depths of our perception of the world. The alterations that occur in the deeds begin within the world of understanding. Once the world of understanding becomes blurred, one can easily see the projections of this on the world of deeds. Given this, sins are deemed unimportant despite our claims of pursuing a religious life, especially in our private lives that we bless! That is what the Prophet warned his followers when he said: "I know some amongst my community; that they shall come to the Judgement Day with clean and brightest deeds like Tihame Mountains. However, on that day Allah shall turn those good deeds into piles of scattered dust." On hearing this one of his companion Sawbān asked: "O, the Messenger of Allah, the Almighty, please do tell us what kind of people are they; tell us so we shall not become one of them without knowing! Then the Prophet explained that: "they are your brothers and sisters. They are human beings like you. They are granted their share of the night's prayer like yourselves. However, they are also the ones 
that underestimate the restrictions and prohibitions of Allah in their privacy; they breach the sacred commandments and violate the law of Allah." ${ }^{35}$

The life style designated for the man by modernity renders sin a common occurrence. Some even says that all punishment is itself a crime. ${ }^{36}$ As long as man commits sins, the barakah in his/her life will diminish. Nevertheless Qur'an underlines the necessity of having faith, fearing Allah and committing good deeds in order to attain a prosperous life. Allah says:

"If the people of the towns had but believed and feared Allah, We should indeed have opened out to them (All kinds of) blessings from heaven and earth; but they rejected (the truth), and We brought them to book for their misdeeds." (Al-Arāf: 7/96)

It is also reported in a number of ahadith that barakah shall diminish due to sins. For instance, the Prophet stated that if a person abandons Friday prayer that person shall not be granted barakah: The Messenger warned the companions as follows:

“... Mark that Allah made Friday prayer an obligation (religious duty) starting from here, from this day, from this month until the Judgement Day. He who abandons this duty in my life time or after my death, in the presence of an imam even a fair or a cruel one; willingly and by denial may Allah not give him His blessings and barakah. Know it! The prayers, alms, hajj, fasting or any deeds of that person shall become vain and empty unless he wishes repentance from Allah. He who wishes repentance from Allah, Allah accepts it..." ${ }^{37}$

Halal earnings are blessed by Allah while Haram earnings are devoid of blessing. It will lead even to the rejection of prayer. The Messenger of Allah says: "O people, Allah is Good and He, therefore, accepts only that which is good. And Allah commands the believers as He commanded the Messengers by saying:

"O Messengers, eat of the good things, and do good deeds; verily I am aware of what you do." (al-Muminun: 23/51). And He said: "O those who believe, eat of the good things that We gave you" (al-Baqarah: 2/172)'...

He then mentioned a person who travels widely, his hair dishevelled and covered with dust. He lifts his hands towards the sky and, thus, makes the $d u$ ' $a$ ': 'O Lord, O Lord,' whereas his food is unlawful, his drink is unlawful, and his clothes are unlawful and his nourishment is unlawful. How can then his $d u^{\prime}$ ' $a$ '

35 Ibn Mājah: 2/1418, hn. 4245; Al-Tabarān̄̄, Sulaymān Bin Aḥmad. Al-Mu'jam As-Sagīr, Ed. Muḥammad Shakūr Maḥmūd al-Hāj Amrir, (Bairut: Dār Ammār, $1^{\text {nd }}$ edition, 1985), 1/396.

36 Osho, The Book of Understanding, (New York: Harmony Books, 2006), p.196.

37 Ibn Mājah: 1/343, hn. 1081; Sunani Al-Bayhaqī Al-Kubrā: 3/171, hn. 5359. 
be accepted?" 38 It has been stated in the sacred scriptures that as the sins of man increase, the barakah shall lessen. As the sins surround every aspect of the life, the blessings of Allah will abandon every aspect of life one by one.

\section{"Barakah" in Modern Times}

In the times that are not dominated by modernity, barakah was more abundant. After modernity barakah became an alienated concept. Thus humanity suffers the results together. We can make a simple comparison between today and past in terms of barakah: The Prophet states an important point in a hadith where he points out the minor signs of the Doomsday:

"Doomsday will not be upon the people as long as the time does not shrink and become tight." 39

In another hadith: "Doomsday will not come if the time does not come closer. This convergence would be so intense that a year passes like a month, a month becomes like a week, a week finishes like a day, a day ends like an hour where as an hour passes in a blink of an eye. $"{ }^{40}$

As the time emerges the movements of earth, it is obvious that what is denoted in the ahadiths is not an increase in the speed of these movements. In the past, one year was 365 days and 6 hours; the same as it is the case today. A month was 30 days in the past and so is today. In the past, one week was equal to 7 days; and the same applies today. A day meant 24 hours in the past and so is today. Yesterday; one hour denominated 60 minutes; and it does the same today. Therefore, what is meant by time convergence and closure? Muslim scholars provided various interpretations, the best interpretation is the ones which most important amongst these is the answer which states explicitly "the decrease of barakah". ${ }^{41}$ We can easily perceive the decrease in barakah by comparing yesterday with today.

For instance today, accessing knowledge is far easier; we have a lot of digital libraries at our disposal. We do not need to look far; just about ten years back researchers had to spend many hours in libraries to retrieve a piece of not so common information. Whereas today we simply type what we are searching for at a blank space provided by the designer and can instantly access the information we seek

38 Muslim: 2/703, hn. 1015; Tirmizī: 5/220, hn. 2989, Al-Dārimī, 'Abdullah Bin 'Abd alRahmān. Sunan al-Dārimī. Ed. Aḥmad Zamralī and Khālid al-Sab' al- 'Ilmīi, (Bairut: Dār alKitāb al-Arabī, $1^{\text {st }}$ edition, 1407 h.), 2/389, hn. 2717.

39 Al-Isfahān̄̄, Abū al-Qāsim al-Husayn Bin Muhammad. Al-Mufradāt F̄̄ Garīb al-Qur'ān, Ed. Muḥammad Sayyid Kīylān̄i, (Bairut: Dār al-Ma rifah), p. 44.

40 Tirmizī: 4/567, hn. 2332; Musnad Ahmmad: 2/537, hn. 10956.

41 See al-Askalān̄̄, Aḥmad Bin Alī Bin Ḥajar, Fath al-Bārī Sharḥi Șaḥịh al-Bukhārī, Ed. Muhammad Fu'ād 'Abd al-Bāqī and Muhīb al-Dīn al-Khatīb, (Bairut: Dār al-Ma rifah), 2 1522; al-Mubārakfūrī, Tuhfatu al-Aḥwazī, 6/514. 
through digital libraries or internet. Depending on the capacity of our computer we can install dozens of digital libraries in our computer and use them at the same time which in turn allows us to do research at many libraries without physically going there. You can simultaneously open as many pages as you like, print the pages you like with unlimited copies and also save the pages to your computer. These digital libraries develop each day with increasing quality. For instance the last version of "al-Maktabat al-Shamilah" prepared in Arabic has more than 6251 books. Many of these books have numerous volumes. The CD called "World's Greatest Classic Books" which is in English contains a great amount of world classics including religious, philosophical and political texts and examples of literature and it contains 3500 books. Along with these digital libraries, when we also consider the sources that can be accessed via internet we can comprehend how easy it is to reach information in today's world. Should not such a facility result a revolution in scientific studies both in terms of quality and quantity?

However, based on the quality and quantity equation, the answer to the question of how much scientific or intellectual work is produced, even by the most diligent academics and a simple comparison between this number and the past underlines the importance of the barakah phenomenon. We can enumerate the names of the scholars who were prolific in producing works in hundreds of volumes even in those technically inadequate situations. This is despite of them having other mundane works to keep themselves busy with. One cannot say that the days of these past scholars were less eventful that they merely concentrated on writing alone. In fact they were doing the same chores like us and even more. They also had responsibilities such as household to look after and also they had many disciples and pupils to educate. Many of them were employed at important positions in the government. Also they were the spiritual and moral guides of the public. And although there were many other obstacles to limit the quality and the quantity of their works but they could produce knowledge which continues to marvel us. While they had to write with chisels that had to be compressed between two fingers and frequently be dipped into ink, we can write with keyboards easily and also can preserve them by copying or saving.

Also there is no instance of such a vast amount of reading that has been exercised in the modern ages. However, all those readings were vain attempts since they could not penetrate the depths of the material. Let the general public aside, even in the academic circles it is now an important skill to read and understand inherited books. A book written by these scholars in those days is rich enough to be a subject of a doctoral thesis.

If this is the situation, then what is the problem? Although there are considerably more opportunities available in our time why then modern man cannot live a prosperous life at least at par with their predecessors? 
The answer to this question, we believe, is the speculation of consuming everything "here" (this world) and "now" (present) that is acquired through the set up of secularism. Modern man consumes all the facilities he has in order to create an idle time to consume them. Thus, in pursuing this vicious circle he has lost his faculties and abilities of seeing, understanding and interpreting, which constitute the foundations of profound thinking. As the activities of scientific creation have turned into a "fast-food" act, the vast majority has lost the interest and curiosity of using the cumulated knowledge in practical life.

We can access information very fast via digital technology, but, we all remain unaware of the process of how the information is generated and furthermore, we try to do things again in the same digital speed. The culture of fast-food age also transformed learning process to the run consumption. Everything must be fast including love and friendship and that too should be "here" and "now". Producing an in-depth and trans-age knowledge from studies does not coincide with the spiritlessness of the age lacking in barakah.

The man of modern era always creates idle time for himself by using technology; which he fills with hedonistic madness at the blink of an eye and replaces barakah with his fast and easy life. It is such a madness that gears prosperous life to be replaced by long life and prosperous wealth by green dollars. And due to this situation, the saying "time is money" has become everyone's life motto. Given this, a promising student with such a point of view chooses fields related to digital technology and not interested in social fields. And many of them discard education in pursuit of money-spinning games. The well-paid footballers stand as irrefutable proofs for this. As time is imbued with materialism, meaning has vaporized and vanished, and the spiritual realm has been replaced by the material domain.

In past, the means of accessing knowledge was limited; however, as the time shrank, they expanded. This barakah was based on "awe" (al-Khushü'). These two concepts are intertwined that it is impossible to talk about awe without barakah or barakah without awe. In one the ahadith it was mentioned that "The first thing to derive from wisdom is awe. ${ }^{42}$ " Ironically, while modernity presents an unbelievable mobility, this mobility lacks barakah in the level of speed it contains; since these movements lack awe.

42 Tirmizī: 5/31, hn. 2653; Dārimī: 1/99, hn. 288; Al-Naysābūrī, Muḥammad Bin Abdullah. AlMustadrak 'Ala Șahīhayn. Ed. Mustafa Abd Al-Qādir 'Itā, (Dār al-Kutub al-'Ilmiy, 1990), 1/179, hn. 338 . 


\section{Conclusion}

Materialistic worldview has turned man into a creature living in a vicious circle which produces to consume and consumes to produce. Concepts such as individuality which are touted as sacred by modernity and its "post" version are the levers of this process. Even a humanitarian statement of individualism can be a means of leading people to the consumption frenzy and all the values and institutions that can stop this disease are destroyed one by one with slogans such as "laissez faire, laissez passer".

As unethical, ill-gotten consumption laden with interest, sex, alcohol, and all other sins becomes the centre of the life, the necessities of a healthy civilization envisioned by Islam such as preservation of religion (al-Din), life (al-nafs), intellect/ reason ( $a l$ - ' $a q l)$, lineage ( $a$ l-nasab), honor ( $a l$-'ird), and property/wealth $(a l-m a l)$ vanish. The dead well into which modernized societies have fallen and also tracking others with them into it is presented as the best social model by those who fail to analyze the modern societies properly. However, modern man has succumbed to depression since he has forgotten God and is searching for a way out.

Modern age made man a miserable being with its perpetual crisis and depression; stripped him of the barakah and abundance of the spiritual world. Modernity declared religion, the true life source which contains the true principles of civilization, as its greatest competitor and condemned human being into the depths of his own deserted conscience and turned this world into a "mangle of paradoxes" for him.

There are stable values for man at all times. Barakah is one of such constant divine values for man. These values must retain their true places in our lives once again. If the heart of humanity and living a dignified life has failed, then we should start to work by restoring the concepts of trueness and reality. This is crucial not only for Muslims but for the entire humanity. The souls which have lost their ontological trust, peace of mind need the tranquillity of religion.

Barakah is not a phenomenon that corresponds to the material income of the people; it can apply itself into every deed of human affairs from love to hope, belief to science. In short, in every corner of life there exists blessing from the Almighty to man. Although with the developments in medicine and genetic sciences, modern age promises a long life that is in conformity with its secular philosophy, but Muslims should be the defenders of a meaningfully prosperous life rather than a mere long life.

The concept of barakah is a divine touch from the spiritual world to the material world. Modernity and its secular paradigm do not reckon and acknowledge the spiritual world, thus they have robbed its concepts and their projections in our lives and endorsed for man a giant emptiness surrounded with material realities. 
Capitalism, a socioeconomic system based on production forged by modernity, carries out unprecedented levels of production performance. Nevertheless, today the number of people that die of hunger has reached its peak. The numbers related to unemployment and poverty have similarly have soared up. Although production performance has excelled, so many people still die of hunger and the reasons behind this absurdity are unethical applications such as the unfair distribution of wealth. It is hard to have barakah without justice; and justice cannot be found in a place where the spiritual dimension is lost. We believe that the main reason behind this laxity of barakah in human life in modern times is related to the profane worldview man so blindly follows. 


\section{Bibliography}

Abu Dāwūd, Sulayman Bin Al-Ash'as, Sunan Abī Dāviud, ed. Muhammad Muhyiddin Abd Al-Hamīd, Dār al-Fikr.

Al-Askalānī, Aḥmad Bin Alī Bin Hajar, Fath al-Bārī Sharhị Ṣah̄ịh alBukhārī, ed. Muḥammad Fu'ād 'Abd al-Bāqī, Muhīb al-Dīn al-Khatīb, Bairut, Dār al-Ma rifah.

Al-'Azīm Ābādī, Muhammad Shamsul Haq, Avn al-Ma'būd Sharh Sunan Abì Dāwūd, 2nd ed., Bairut, Dār al-Kutub al-'īlmiy, 1995.

Al-Bayhaqī, Aḥmad Bin Ḥossain, Sunani Al-Bayhaqī Al-Kubrā, ed. Muḍammad Abd Al-Qādir Atā, Makkah, Dār Al-Bāz, 1994.

Al-Bukhārī, Muhammad Bin Ismāil, Șahīh al-Bukhārī, 3th ed., ed. Mustafā Dīb al-Bughā, Bairut, Dār Ibn Kashir al-Yamāma.

Al-Dārimī, 'Abdullah Bin 'Abd al-Rahmān, Sunan al-Dārimī, ed. Aḥmad Zamralī, Khālid al-Sab' al- 'Ilmī, Bairut, Dār al-Kitāb al-Arabī, 1407 h.

Al-Fayrūz Ābādī, Muhammad Bin Yaqūb, Al-Qamūs al-Muhīt, Bairut, Muassasat al-Risālah.

Al-Isfahān̄̄, Abū al-Qāsim al-Husayn Bin Muḥammad, Al-Mufradāt F̄̄ Garīb al-Qur'ān, ed. Muḥammad Sayyid Kīylānī, Bairut: Dār al-Ma rifah.

Al-Mubārakfūrī, Muḥammad Bin 'Abdu Rahman bin 'Abdu Rahim, Tuhfatu al-Aḥwaz̄̄ Bi Sharḥ̄ al-Jāmī al-Tirmizī, Bairut, Dār al-Kutub al- 'Ilmiy.

Al-Nawawī, Yahyā Bin Sharaf bin Mary, Sharḥ al-Nawawī 'Alā Șaḥịh Muslim, 2nd ed., Bairut, Dār Ihyā al-Turath al- 'Arabī, 1392 h.

Al-Naysābūrī, Muḥammad Bin Abdullah, Al-Mustadrak 'Ala Șahīhayn, ed. Mustafa Abd Al-Qādir 'Itā, Dār al-Kutub al-'Ilmiy, 1990.

Al-Qazwīnī, Muḥammad Bin Yazīd, Sunan Ibn Mājah, ed. Muḥammad Fu'ad 'Abd al-Bāqī', Bairut, Dār al-Fikr.

Al-Qushayrī, Muslim Bin Hajjāj. Șaḥịh Muslim, ed. Muhammad Fu'ad 'Abd al-Bāqīe Bairut, Dār Ihyā al-Turath al- 'Arabī.

Al-Tabarānī, Sulaymān Bin Aḥmad, Al-Mu'jam Al-Kabīr, 2nd ed., ed. Haamdī Bin Abd Al-Majīd al-Salafī, Musul, Maktabatu al-Ulūm wa al-Ḥikam, 1983. , Al-Mu'jam As-Sagīr, ed. Muhammad Shakūr Maḥmūd alHāj Amrir, Bairut, Dār Ammār, 1985.

Al-Tirmizī, Muḥammad Bin 'Isā, Sunan al-Tirmizīe ed. Aḥmad Muhammad Shākir, Bairut, Dār Ihyāa al-Turath al-Arabī.

Chelhod, Joseph, "La baraka chez les Arabes ou l'influence bienfisante du 
sacré", Revue de l'histoire des religions, 148, 1955.

Gillespie, Michael Allen, The Theological origins of Modernity, Chicago / London, The University of Chicago Press, 2008.

Ibn Ḥanbal, Abū 'Abdullah Aḥmad al-Shaybān̄i, Musnad Aḥmad, Egypt, Muassasat Qurtubah.

Ibn Ḥibbān, Muḥammad Bin Aḥmad Abū Ḥātim, Șahīh Ibn Hiibbān, ed. Shuayb al-Arnawūt, 2nd ed., Bairut, Muassasat al-Risālah, 1993.

Ibn Manẓūr, Muḥammad Bin Makram, Lisān al- 'Arab, Bairut, Dār Ṣādir.

Ibn Qaiyyim al-Jawziyah, Abi 'Abd Allāh Muhammad ibn Abi Bakr al-Dimashqi, Badā'i 'al-Fawā’id, 2nd ed., Misr, Maktabat al-Qāhirah, 1972.

Lawhead, William F, The philosophical journey: an interactive approach, 5th ed., New York, McGraw-Hill, 2009.

Osho, The Book of Understanding, New York, Harmony Books, 2006.

Mitchell, Christopher Wright, The Meaning of BRK "To Bless" in the Old Testament, Atlanta, Scholars Press, 1987.

Schwarzmantel, John, The Age of Ideology: Political Ideologies from the American Revolution to Postmodern Times, New York, NYU Press, 1998.

Thomas, Steve-See Paine, Thomas, The Age of Reason, South Australia, The University of Adelaide, 2010. 